\title{
PENGEMBANGAN MEDIA PEMBELAJARAN MAHASISWA PAI BERBASIS WHATSHAPP
}

\author{
Muhammad Jamil Hadi \\ Pascasarjana Universitas Islam Negeri Maulana Malik Ibrahim Malang \\ Pendem, Junrejo, Kota Batu, Jawa Timur, Indonesia \\ Email: jamelhadi93@gmail.com
}

\begin{abstract}
Abstrak
Pembelajaran dapat berjalan efektif jika unsur-unsur pembelajaran dapat terpenuhi dalam proses pembelajaran. Factor pendukung keberhasilan itu juga tidak lepas dari penggunaan teknologi sebagai media pembelajaran yang lebih menarik dan memenuhi kebutuhan pendidik dan peserta didik. Oleh sebab itu untuk mempermudah kegiatan mengajar terutama dalam pembelajaran Pendidikan Agama Islam (PAI) seorang pendidik hendaknya mampu mengembangkan media pembelajaran berbasis teknologi. Aplikasi Whatsapp merupakan media komunikasi yang dapat dikembangkan sebagai media pembelajaran interaktif oleh mahasiswa PAI. Dengan mengembangkan media pembelajaran berbasis Whatsapp, dosen dan mahasiswa dapat melakukan proses pembelajaran secara jarak jauh (Distance Learning). Methode penelitian ini menggunakan metode penelitian dan pengembangan (Research and Development) yaitu dengan cara mengembangkan suatu produk kemudian dikembangkan dengan menguji keefektifan produk tersebut. Kemudian model penelitian menggunakan model CTL yaitu, model pembelajaran berbasis problematic, memanfaatkan lingkungan peserta didik untuk memperoleh kegiatan pembelajaran, memberikan aktivitas kelompok, membuat aktivitas belajar mandiri, membuat aktivitas belajar bersama masyarakat (Prihantoro, 2015). Tahapan yang perlu diperhatikan dalam mengembangkan aplikasi media pembelajaran adalah: 1.) menentukan konsep dan model pembelajaran, 2.) menentukan kompetensi dasar yang akan dicapai peserta didik, 3.) menentukan materi yang akan dimuat dalam media pembelajaran, 4.) menentukan evaluasi yang digunakan untuk mengetahui sejauh mana keberhasilan media pembelajaran yang digunakan.

Kata Kunci : Pengembangan, Media Pembelajaran, Whatsapp
\end{abstract}

\section{PENDAHULUAN}

TEKNOLOGI Informasi dan Komunikasi semakin hari semakin berkembang dengan kemajuan jaman, karena dipengaruhi berbagai aspek kebutuhan manusia sehingga berfikir dan mengembangkan teknologi untuk dapat membantu kehidupan sehari-hari. Dikaitkan dengan pembelajaran maka teknologi merupakan media yang tidak bisa dipisahkan oleh aspek keberhasilan proses pembelajaran. Hal ini, dapat kita lihat ketika teknologi tidak hanya sebagai informasi akan tetapi juga sebagai alat komunikasi untuk menyampaikan pembelajaran. Dalam hal tersebut, komunikasi merupakan hal mutlak yang diperlukan dalam proses pembelajaran. Ada beberapa komponen penting yang menentukan efektivitas proses 
pembelajaran,yaitu adalah guru, peserta didik, materi, metode, media dan situasi (Asyhar, 2012) pengertian pembelajaran menurut UU Sisdiknas No 20 Tahun 2003:

"Pembelajaran adalah proses interaksi peserta didik dengan pendidik dan sumber belajar pada suatu lingkungan belajar. Pembelajaran sebagai proses belajar yang dibangun oleh guru untuk mengembangkan kreatifitas berfikir yang dapat meningkatkan kemampuan berfikir peserta didik serta dapat meningkatkan penguasaan yang baik terhadap materi pembelajaran."

Pembelajaran merupakan sistem yang dibuat oleh guru sebagai upaya untuk membuka ruang pikiran peserta didik agar dapat mengembangkan sistem kreatifitas diri. Sehingga mampu menjadi manusia yang diharapkan untuk menerapkan apa yang telah didapatkan dari materi pembelajaran dengan baik dan dapat memecahkan masalah disetiap kehidupan yang dihadapi. Karena peserta didik merupakan subjek yang menjadi pusat kegiantan belajar. Maka, peserta didik dituntut harus aktif, menemukan, menganalisa sehingga dapat menyimpulkan suatu masalah.

Pendidikan Agama Islam (PAI) menurut Zakiyah Darajdat yang dikutip Abdul Majid dan Dian Andayani (Andayani, 2004), Pendidikan agama Islam adalah suatu usaha untuk membina dan mengasuh peserta didik agar senantiasa dapat memahami ajaran islam secara menyeluruh, lalu menghayati tujuan, yang pada akhirnya dapat mengamalkan serta menjadikan islam sebagai pandangan hidup.

Pemahaman ini, dapat dipahami bahwa fungsi dari pendidikan agama islam adalah upaya yang dilakukan dalam menanamkan nilai-nilai pendidikan yang diajarkan dalam agam islam sehingga dengan membangun pondasi jiwa spiritual peserta didik dengan baik, maka hasil yang dibuktikan melalui tindakan merupakan tujuan pendidik dalam pembelajaran. Hal ini diharapkan adanya perubahan peserta didik baik secara efektif, kognitif maupun psikomotorik.

Pemaknaan pembelajaran pendidikan agama islam merupakan hal yang berpengaruh untuk menjadikan peserta didik yang memiliki jiwa muslim yang taat akan ajaran agama islam dan mampu merealisasikan dalam bersosial dimasyarakat maupun bermuamallah dengan Allah swt. Dengan membangun pondasi peserta didik sejak dini diharapkan mampu memperkokoh benteng keimanan dalam menjalankan kehidupan sehari-hari.

Sebagai pendidik juga memiliki peran sebagai sumber belajar yang penting, karena sebagai pelaku utama dalam proses pembelajaran pendidik harus mampu menyampaikan materi pelajaran sebaik mungkin. Jadi hal penunjang seperti halnya media, bahan ajar dan 
lainya tidak akan berjalan tanpa ada yang mengatur sebagai regulator transfer of knowlage dalam pembelajaran. Jika seorang pendidik tidak mampu menyampaikan materi dengan baik dan gagal menjalankan peran sebagai pendidik maka akan membuat peserta didik menjadi jenuh, bosan kurang memperhatikan pelajaran sampai akhirnya menghambat tujuan dalam proses pembelajaran.

Fungsi media dalam pembelajaran menjadi sorotan utama yang diperhatikan diera modern ini. Bahkan seorang pendidik tanpa menyampaikan materi secara langsung, sekarang dapat diwakilkan dengan kecanggihan teknologi yang semakin berkembang. Karena dengan adanya teknologi yang modern peserta didik cenderung lebih tertarik dengan hal yang baru. Tugas utama guru dalam menghadapi perkembangan teknologi ini adalah dengan cara mengintegrasikan pendidikan agama islam dengan teknologi.hal ini dipandang lebih efektif dalam proses pembelajaran melalui media-media pembelajaran yang menarik.

Menurut Briggs dan Gagne dalam (Arsyad, 2009) mengatakan bahwa media pembelajaran meliputi alat yang secara fisik digunakan untuk menyampaikan isi materi pengajaran, yang terdiri dari; Buku, tipe recorder, kaset, Vidio, kamera, video recorder, film, slide (gambar bingkai), foto, gambar, grafik, grafik televisi dan computer. Dalam hal berarti media adalah komponen sumber belajar peserta didik untuk belajar.

Pada masa ini, media belajar yang digunakan guru seperti halnya berupa gambar, video, kaset, bahkan computer sudah menjadi hal yang mudah dijumpai dalam proses pendidikan. Akan tetapi, perlu diperhatikan pada abad 20-an ini media internet sudah menjadi hal utama dalam proses pembelajaran, bahkan lebih penting dari seorang pendidik. Karena seperti yang kita ketahui manusia dapat belajar tanpa guru dan hanya menggunakan media gadget yang terhubung dengan internet. Hal ini disamping membantu pendidik dalam proses pembelajaran akan tetapi tanpa pengawasan maka menjadi boomerang yang menjadikan peserta didik salah arah dalam pembelajaran.

Penggunaan media memerlukan pertimbangan yang baik untuk disesuaikan keperluan peserta didik. Kesesuaian media dengan peserta didik menjadi dasar utama, karena penggunaan media juga disesuaikan dengan tingkat usia peserta didik. Perlu perancangan yang matang sehingga media dapat tepat sasaran dalam penggunaanya (Riyana, 2009). Penggunaan media dijenjang SD tentunya tidak sama dengan penggunaan media pembelajaran dijenjang SMA, bahkan diperguruan tinggi. 
Oleh sebab itu, ada beberapa media pembelajaran dalam diskusi mahasiswa Pendidikan Agama Islam yang mudah dan dapat dimanfaatkan sesuai kebutuhan dalam forum diskusi. Dalam proses pembelajaran yang dilakukan secara dalam jaringan (daring) maka, beberapa dosen atau pendidik menggunakan media pembelajaran berbasis teknologi. Teknologi tersebut berupa aplikasi yang tersedia di smartphone/gadget pengguna. Aplikasi yang dapat digunakan dalam pembelajaran daring diantaranya berupa google class meeting, E-Learning, google class room, zoom, edmodo dan lain lain. Selain itu aplikasi sebagai alat komunikas yang sering digunakan dalam menyampaikan pesan pembelajaran adalah aplikasi Whatsapp.

\section{PENGERTIAN APLIKASI WHATSAPP}

WhatsApp adalah aplikasi pesan instan untuk smartphone, jika dilihat dari fungsinya WhatsApp hampir sama dengan aplikasi SMS yang biasa Anda pergunakan di ponsel lama. Tetapi WhatsApp tidak menggunakan pulsa, melainkan data internet. Jadi, di aplikasi ini tak perlu khawatir soal panjang pendeknya karakter. Tidak ada batasan selama data internet memadai. Jadi, sistem pengenalan kontak, verifikasi dan pengiriman pesan tetap dilakukan melalui nomor ponsel yang sudah terlebih dahulu didaftarkan. Cara ini berbeda dengan BBM yang menggunakan PIN, ataupun LINE yang selain nomor ponsel juga mendukung email, dan nama pengguna. Aplikasi Whatsapp adalah media yang familiar digunakan jutaan manusia dalam berkomunikasi. Media ini tergolong paling efesien dalam menyampaikan pesan terkhusus informasi penting dalam jangkauan internet.

Selain mempunyai fitur untuk menyampaikan pesan, aplikasi ini juga mempunyai beberapa fitur yang dapat kita gunakan dalam kebutuhan proses pembelajaran, yaitu mengirim foto dari galeri ataupun dari kamera, mengirim video, mengirim berkas-berkas persentasi (PDF, Microsofe word, powe point dan lain-lain), menelpon melalui suara termasuk mengirim pesan suara yang dapat didengar oleh penerima setiap saat, berbagi lokasi menggunakan GPS, mengirimkan kartu kontak, Whatsapp juga mendukung beberapa emoji namununtuk stiker watshaap tergolong minimalis, di watshaap pengguna dapat mengatur profil sendiri.

\section{METODE PENELITIAN}

Metode penelitian ini menggunakan metode penelitian dan pengembangan (Research and Development) yaitu dengan cara mengembangkan suatu produk kemudian dikembangkan dengan menguji kefektifan produk tersebut. Kemudian model pembelajaran 
yang digunakan adalah model pembelajaran CTL. Model pembelajaran CTL adalah salah satu pendekatan pembelajaran yang menekankan pada belajar secara kelompok untuk mampu menemukan suatu konsep yang dihubungkan dengan kehidupan nyata. Penerapan CTL adalah pembelajaran berbasis problematic, memanfaatkan lingkungan peserta didik untuk memperoleh kegiatan pembelajaran, memberikan aktivitas kelompok, membuat aktivitas belajar mandiri, membuat aktivitas belajar bersama masyarakat (Prihantoro, 2015).

Model pembelajaran ini merupakan model pembelajaran mandiri yang menekankan peserta didik lebih aktif dalam proses pembelajaran. Model ini merupakan contoh model yang diterapkan diperguruan tinggi. Sebagai pendidik hanya memberikan arahan dalam proses pembelajaran berlangsung. Adapun karakteristik pembelajaran CTL adalah

1. peserta didik secara aktif terlibat dalam proses pemebelajaran.

2. Peserta didik belajar dari teman melalui kerja kelompok, diskusi dan saling mengoreksi.

3. Pembelajaran dikaitkan dengan kehidupan nyata.

4. Prilaku dibangun atas kesadaran diri.

5. Keterampilan dikembangkan atas dasar pemahaman.

6. Peserta didik menggunakan kemampuan berpikir kritis, terlibat penuh dalam mengupayakan terjadinya proses pembelajaran efektif dan membawa skema masingmasing kedalam proses pembelajaran (M.S. Hidayat, 2012:231-247).

Untuk menerapkan model pembelajaran ini, ada beberapa langkah strategi dalam penerapanya. Hal yang perlu dilakukan pendidik dalam menggunakan model ini adalah:

1. Memberikan masalah.

2. Peserta didik mendiskusikan masalah dan mengidentifikasi masalah.

3. Pembelajaran dalam konteks kehidupan peserta didik.

4. Belajar bersama (collaboration learning).

5. Penilaian otentik (Suhardin, 2018: 124-134).

\section{PENGEMBANGAN PEMBELAJARAN APLIKASI WHATSAPP}

Sebelum menggunakan aplikasi Whatsapp sebagai media pembelajaran, ada beberapa tahapan yang harus diperhatikan, supaya hasil pengembangan dari pemanfaatan media dari aplikasi Whatsapp dapat terealisasikan sesuai yang diinginkan. Tahapan yang perlu diperhatikan dalam mengembangkan aplikasi media pembelajaran adalah: 1.) menentukan konsep dan model pembelajaran, 2.) menentukan kompetensi dasar yang akan dicapai peserta 
didik, 3.) menentukan materi yang akan dimuat dalam media pembelajaran, 4.) menentukan evaluasi yang digunakan untuk mengetahui sejauh mana keberhasilan media pembelajaran yang digunakan.

Menurut Yusuf Hadi Miarso, ada beberapa hal yang harus diperhatikan dalam menggunakan media pembelajaran, diantaranya; ${ }^{1}$

1. tidak ada suatu media yang terbaik untuk mencapai suatu tujuan pembelajaran. Masing-masing media mempunyai kelebihan dan kekurangan. Oleh karena itu pemanfaatan kombinasi dua atau lebih media akan lebih mampu membantu tercapainya tujuan pembelajaran.

2. Penggunaan media harus berdasarkan tujuan pembelajaran yang hendak dicapai. Dengan demikian pemanfaatan media harus menjadi bagian integral dari penyajian pelajaran.

3. Penggunaan media harus mempertimbangkan kecocokan ciri media dengan karakteristik materi pelajaran yang disajikan.

4. Penggunaan media harus disesuaikan dengan bentuk kegiatan belajar mengajar yang akan dilaksanakan seperti belajar secara klasikal, belajar dalam kelompok kecil, belajar secara individual atau belajar mandiri.

a. penggunaan media harus disertai persiapan yang cukup seperti preview media yang dipakai, mempersiapkan berbagai peralatan yang dibutuhkan saat proses pembelajaran sebelum proses pembelajaran dimulai.

b. peserta didik perlu disiapkan sebelum media pembelajaran digunakan, agar mereka dapat mengarahkan perhatian pada hal-hal yang penting selama penyajian dengan media berlangsung.

c. Penggunaan media harus diusahakan agar senantiasa melibatkan partisipasi aktif peserta didik.

Tahap-tahap pengembangan dalam penggunaan media Whatsapp dalam pembelajaran mahasiswa PAI pascasarjana UIN Malang dengan menggunakan model CTL, yang menekankan peserta didik yaitu mahasiswa lebih aktif dalam penggunaanya. Dalam proses pembelajaran dalam aplikasi Whatsapp ini seorang pendidik menggunakan fitur groub

\footnotetext{
${ }^{1}$ Yusufhadi Miarso, Menyemai Benih Teknologi Pendidikan, (Jakarta. Kencana Media Groub 2004) h. 461

Al Qalam: Jurnal Ilmiah Keagamaan dan Kemasyarakatan

Vol. 15, No. 1, Januari-Juni 2021
} 
Whatsapp dalam pengembangan pembelajaran. Adapun tahap pengembangan tersebut adalah:

1. Dosen/Pendidik

Tugas-tugas pendidik dalam pembelajaran adalah:

a. Membuat forum groub Whatsapp.

b. Mempersiapkan langkah-langkah aturan dalam diskusi menggunakan media ini.

c. Memberikan Sub Materi yang akan dibahas dalam setiap pertemuan.

d. Menjelaskan tujuan pembelajaran dengan menggunakan media Whatsapp.

e. Mengevaluasi setiap pertemuan materi yang dibahas.

f. Membuat forum absensi di groub Whatsapp.

\section{Mahasiswa/Peserta Didik}

Tugas mahasiswa dalam proses pembelajaran dengan menggunakan media Whatsapp:

a. Mengisi absensi yang telah dibuatkan dosen.

b. Membuat kelompok belajar, kemudian dibagi permateri.

c. Memahami ketentuan aturan diskusi dalam pembelajaran.

d. Mengisi absensi yang dibuatkan dosen.

e. Membuat makalah dan power point materi yang sudah dibagikan.

f. Berdiskusi (Tanya jawab, sanggahan serta tambahan) dari materi yang dibahas oleh pemateri disetiap pertemuan.

g. Mengerjakan setiap tugas yang diberikan dosen.

Dalam proses pembelajaran berlangsung dosen dan mahasiswa memanfaatkan fitur aplikasi ini dengan sebaik-baiknya. Karena aplikasi ini sangat mudah digunakan maka, antara mahasiswa dan dosen dapat menjaga privasi etika masing-masing menjadi lebih terkontrol dan efesian digunakan. Sebagai media komunikasi aplikasi ini juga dapat dikembangkan menjadi media pembelajaran yang interaktif bagi pendidikan.

\section{IMPLEMENTASI MEDIA PEMBELAJARAN WHATSAPP MAHASISWA PAI}

Proses pembelajaran dengan menggunakan media Whatsapp peneliti mengambil contoh mahasiswa PAI Pascasarjana UIN Malang semester 2. Implementasi media pembelajaran ini dilaksanakan ditengah situasi pandemic covid 19, sehingga pembelajaran secara langsung dikampus tidak memungkinkan dilaksanakan. Oleh karena, itu beberapa dosen memberikan arahan materi perkuliahan dengan sarana E-learning dan aplikasi lainya yang memungkinkan tetap terlaksananya perkuliahan. Matakuliah yang menggunakan media 
Whatsapp yang digunakan mahasiswa semester 2 ini adalah "Pengembangan Media Pembelajaran PAI".

Untuk memulai perkuliahan langkah awal dosen membuat fitur groub Whatsapp kelas yang ada di aplikasi Whatsapp. Dosen membuat groub dengan nama "S2 PAI Peng Media" Contoh Gambar sebagai berikut:

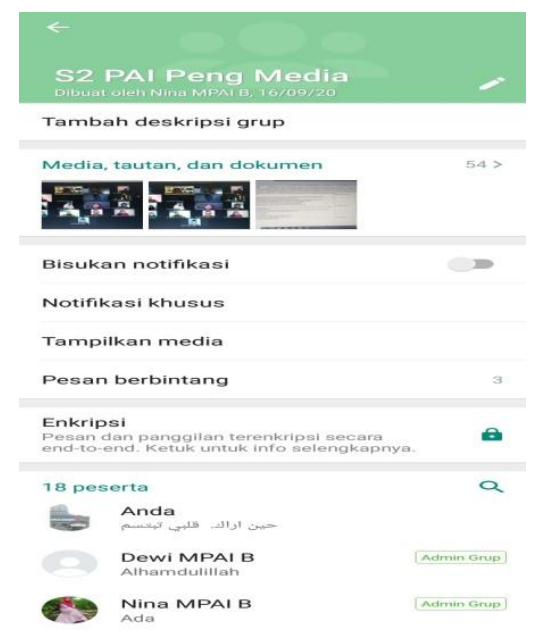

Setelah dosen membuat groub kelas dosen memasukkan anggota kelas kedalam groub, kemudian memulai dengan salam dan membuat list kehadiran mahasiswa. Contoh gambar sebagai berikut:

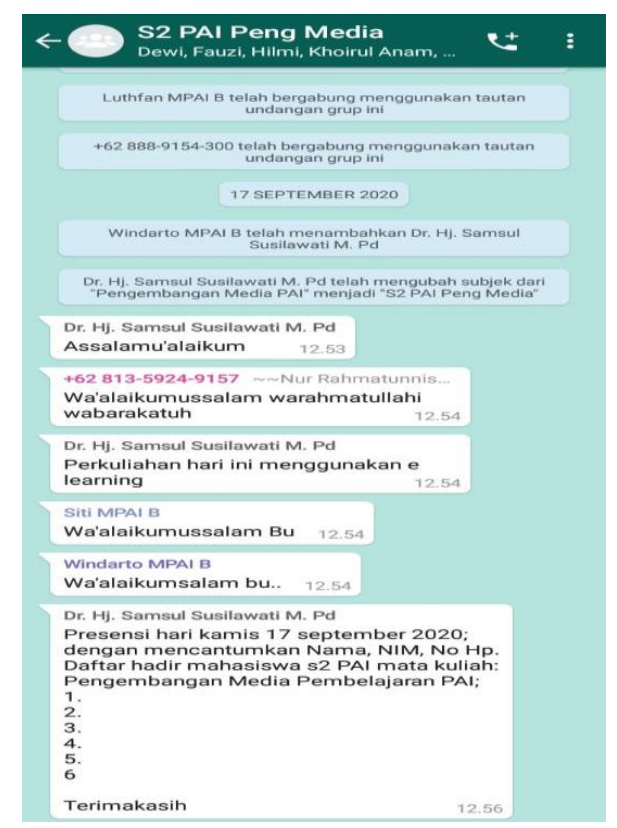

Kemudian mahasiswa mulai mengisi list absen yang telah disediakan dosen. Setelah itu guru memberi arahan perkuliahan untuk semester kedepan. Diawal pertemuan digroub 
Whatshapp ini, antara dosen dan mahasiswa melakukan kontrak kuliah dan memberikan penugasan perkuliahan selama semester kedepan. Contoh gambar sebagai berikut:

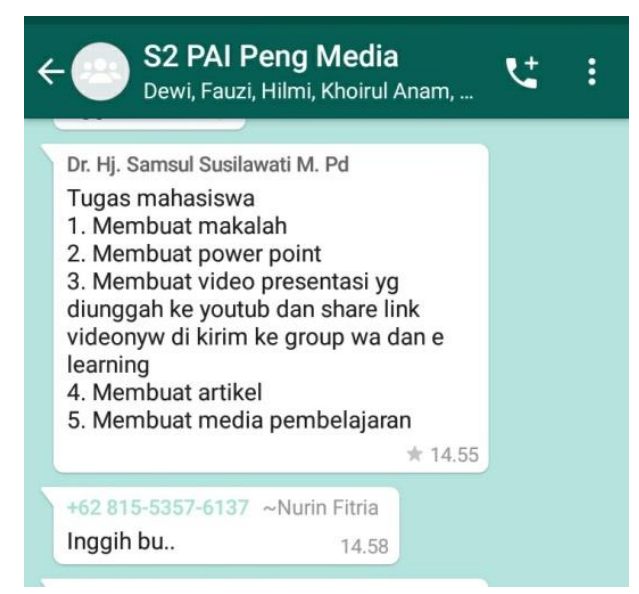

Setiap mahasiswa setelah menerima tugas dari dosen kemudian mengerjakan sesuai kelompok masing-masing. Untuk persentasi dosen memberikan tugas selain membuat makalah dan power point tugas mahasiswa adalah membuat video persentasi yang diuploud diyoutube. Sehingga ketika pertemuan setiap minggu digroub Whatsapp mahasiswa yang bertugas menyampaikan materi hanya mengirim file makalah, power point dan link video persentasi yang sudah diuploud diyoutube. Contoh gambar sebagai berikut: 


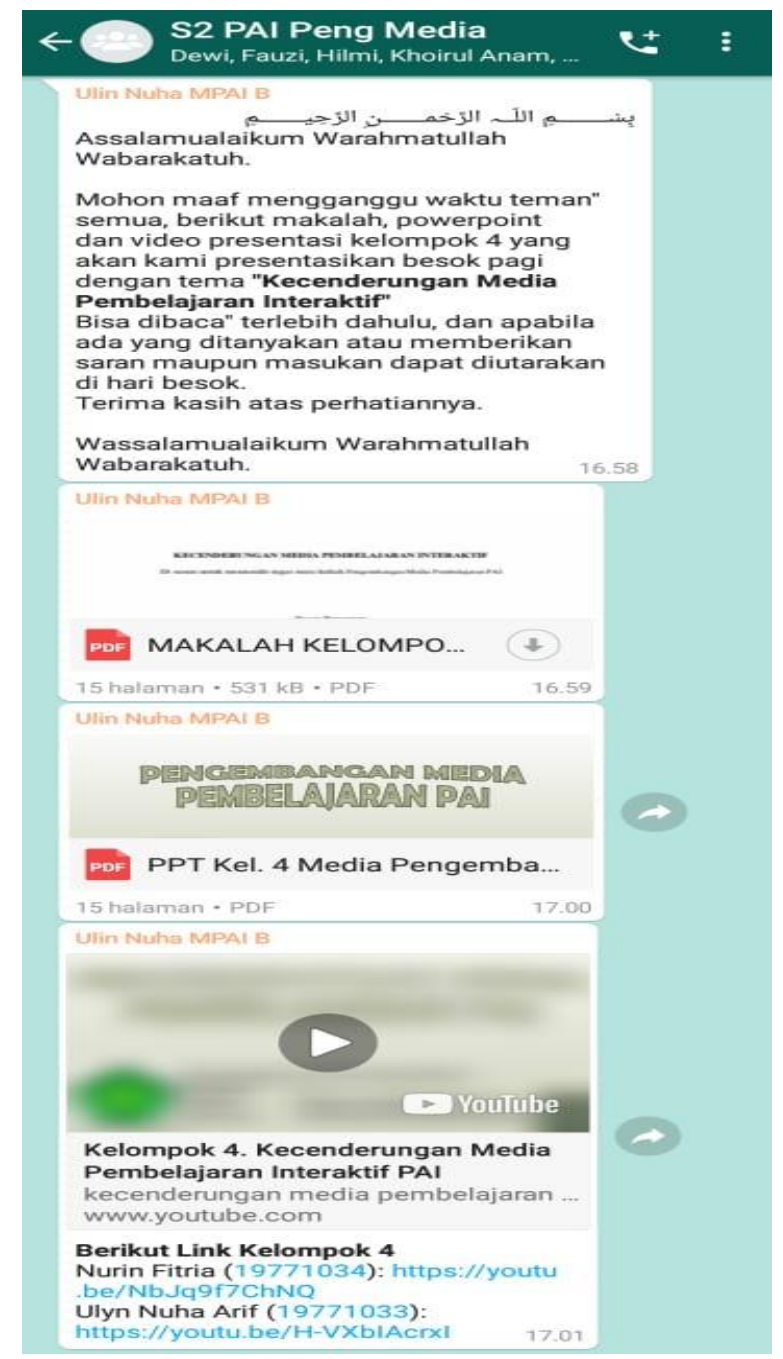

Setelah mahasiswa yang bertugas persentasi mengirim file digroub, mahasiswa yang bertugas sebagai moderator memandu jalanya diskusi digroub kelas. Dalam diskusi tersebut siswa dituntut lebih aktif dalam bertanya dan memberikan ide ide segar dan menarik terkait meteri diskusi.

Proses aplikasi pengembangan media pembelajaran ini, melatih mahasiswa untuk gemar menulis ide ide pokok pikiran dengan tulisan digroub Whatsapp. Sistem diskusi di groub ini adalah moderator memberikan waktu kepada audience untuk bertanya kepada pemateri, setelah pertanyaan disampaikan melalui pesan ketik di groub Whatsapp kemudian pemateri memberikan jawaban dan tanggapan terkait soal yang diberikan. Selain petugas persentasi, penanya dan moderator yang aktif mahasiswa lain juga diberikan kesempatan untuk mengomentari dan memberi gagasan ataupun solusi terkait persoalan materi yang ditanyakan. Setelah proses diskusi dilaksanakan dan dosen memberi arahan terkait materi 
yang dipersoalkan atau didiskusikan oleh mahasiswa. Kemudian diakhir sesi diskusi moderator memberikan kesimpulan hasil diskusi. Contoh gambar sebagai berikut:

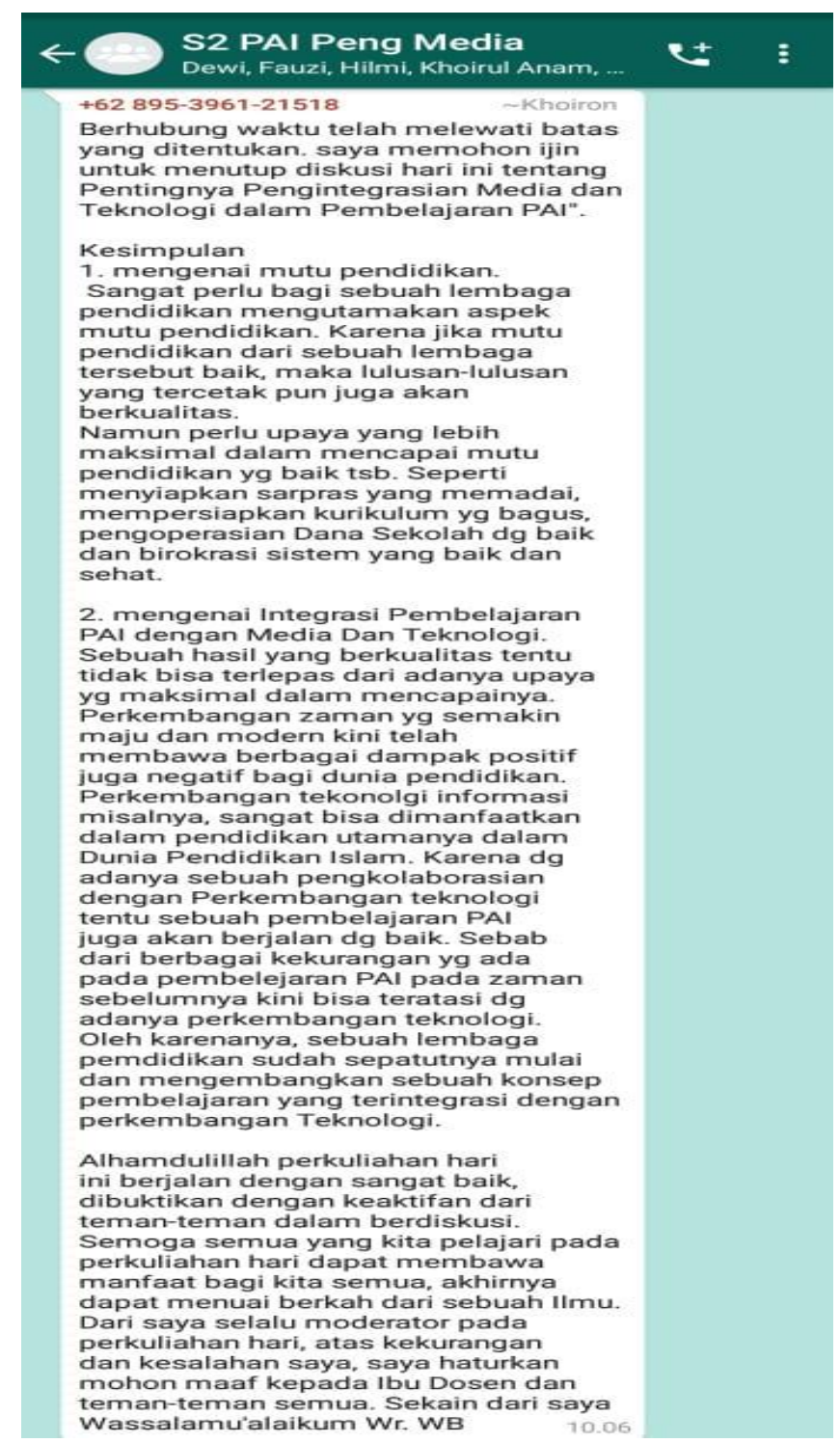

Proses perkuliahan Media Pengembangan Pembelajaran PAI S2 ini berlangsung selama 3 SKS atau 3 jam pembelajaran. Selama proses perkuliahan dilaksanakan dengan tertib dan sesuai jadwal yang sudah ditentukan. Perkuliahan ini dimulai dari awal oktober sampai ujian akhir semester yaitu akhir bulan desember 2020. Proses perkuliahan dengan menggunakan media Whatsapp ini tidak hanya pada matakuliah media pengembangan pembelajaran PAI saja, namun matakuliah yang lainya juga menggunakan media ini. Karena selain sebagai media telekomunikasi media Whatsapp juga dapat digunakan sebagai media pembelajaran yang lebih simple, efesien dan mudah digunakan dari pada aplikasi lainya. 
Untuk pengembangan media pembelajaran aplikasi ini sangat membantu mahasiswa dalam proses perkuliahan yang dilakukan secara daring. Untuk itu, pemanfaatan teknologi sebagai sarana media pembelajaran dapat meningkatkan mutu pendidikan dilembaga pendidikan khususnya di perguruan tinggi negeri.

\section{MANFAAT, KELEBIHAN DAN KEKURANGAN}

Setiap media pembelajaran tidak lepas dari kekurangan dan kelebihanya, secara akademik aplikasi ini memiliki manfaat dalam pengembangan media pembelajaran. Disituasi yang diharuskan proses pembelajaran dengan sistem daring karena pandemic covid 19, solusi menggunakan menggunakan media ini, lebih mudah digunakan oleh khalayak ramai apalagi didalam dunia pendidikan. Untuk itu penggunaan media pembelajaran dengan menggunakan a plikasi ini mempunyai beberapa kelebihan diantaranya :

1. Sebagai media komunikasi juga dapat digunakan sebagai media pembelajaran.

2. Lebih mudah digunakan untuk menyampaikan pesan informasi sehingga sesuai digunakan sebagai sarana diskusi di fitur groub Whatsapp.

3. Tidak ada batasan dalam penulisan kata dalam pesan

4. Memiliki banyak fitur yang dapat digunakan seperti video call groub, pengiriman gambar, foto, dokumen, dan lain-lain.

5. Lebih murah biaya pembayaran paket data jika berdiskusi dengan fitur chatting digroub.

6. Mudah digunakan sebagai kebutuhan komunikasi.

Adapun kekuranganya meskipun bisa diatasi dengan beberapa cara akan tetapi masih menjadi kendala yang tetap harus diperbaiki sebagai media pembelajaran yang lebih baik. Untuk kekurangan dari aplikasi ini sebagai media pembelajaran adalah:

1. Kendala sinyal internet, membuat aplikasi Whatsapp sulit terhubung dalam mode online.

2. Pendidik sulit mengamati peserta didik secara virtual.

3. Keterbatasan peserta audience dalam menggunakan fitur video call.

4. Suara kurang jelas ketika melakukan video call lebih dari dua orang.

5. Sulit konsentrasi ketika diskusi, karena pesan masuk groub yang begitu banyak ketika membaca kemudian muncul pesan/tanggapan baru dari audience.

6. Tidak bisa lebih luas menggambarkan pikiran dalam tulisan diforum diskusi karena terbatas waktu menulis dibandingkan berbicara lewat audio. 


\section{KESIMPULAN}

Teknologi merupakan media yang tidak bisa dipisahkan oleh aspek keberhasilan proses pembelajaran. Karena dengan adanya teknologi yang modern peserta didik cenderung lebih tertarik dengan hal yang baru dalam pembelajaran. Menurut Briggs dan Gagne dalam (Arsyad, 2009) mengatakan bahwa media pembelajaran meliputi alat yang secara fisik digunakan untuk menyampaikan isi materi pengajaran, yang terdiri dari; Buku, tipe recorder, kaset, Vidio, kamera, video recorder, film, slide (gambar bingkai), foto, gambar, grafik, grafik televisi dan computer.

WhatsApp adalah aplikasi pesan instan untuk smartphone, Aplikasi Whatsapp adalah media yang familiar digunakan jutaan manusia dalam berkomunikasi. Media ini tergolong paling efesien dalam menyampaikan pesan terkhusus informasi penting dalam jangkauan internet. Metode penelitian ini menggunakan metode penelitian dan pengembangan (Research and Development) yaitu dengan cara mengembangkan suatu produk kemudian dikembangkan dengan menguji kefektifan produk tersebut.

Ada beberapa tahap untuk mengembangkan aplikasi Whatsapp sebagai media pembelajaran, yaitu : 1.) menentukan konsep dan model pembelajaran, 2.) menentukan kompetensi dasar yang akan dicapai peserta didik, 3.) menentukan materi yang akan dimuat dalam media pembelajaran, 4.) menentukan evaluasi yang digunakan untuk mengetahui sejauh mana keberhasilan media pembelajaran yang digunakan. Dalam mengembangkan aplikasi ini ada beberapa tugas yang dilakukan oleh seorang pendidik dan peserta didik. Untuk penerapanya di dalam proses pembelajaran juga memiliki manfaat menggunakan media ini, yaitu lebih mudah digunakan oleh khalayak ramai apalagi didalam dunia pendidikan, kelebihannya selain sebagai media komunikasi juga bisa digunakan sebagai media pembelajaran. Sedangkan, kekurangan media ini adalah kendala sinyal internet yang berdampak kepada terhentinya proses pembelajaran, hal ini yang harus dievaluasi dengan harapan menjadi media pembelajaran yang lebih baik.

\section{DAFTAR PUSTAKA}

Miarso, Yusufhadi. 2004. Menyemai Benih Teknologi Pendidikan. Jakarta: Kencana Media Groub

Asyhar, R. 2012. Kreatif Mengembangkan Media Pembelajaran. Jakarta: Referensi Jakarta. 
Arsyad, A. 2009. Media Pembelajaran. Jakarta: Radja Grafindo Persada.

Riyana, R. S. \& C. 2009. Media Pembelajaran, Hakikat, Pengembangan, Pemanfaatan dan Penilaiaan. Bandung: Wahana Pri.

Prihantoro, A. 2015. Pendekatan Contextual Teaching and Learning dalam Pembelajaran Fiqh di MTS Ma'arif Argopeni Ayah Kebumen. Purwokerto: IAIN Purwokerto.

Suhardin. 2018. Pengaruh Strategi Pembelajaran Contextual Teaching Learning dan Integrated Instructional Terhadap Kemampuan Berfikir Kritis Siswa Tentang Zakat. Edukasi: Jurnal Penelitian Pendidikan Agama dan Keagamaan, 16 (2), 124-137.

Ansari, Chairul, dkk. 2016. Penetrasi \& Perilaku Pengguna Internet Indonesia. Asosiasi Penyedia Jasa Internet Indonesia (APJII). https://www.apjii.or.id/survei2016

Sugiyono. 2009. Metode Penelitian Pendidikan Pendekatan Kuantitatif, Kualitatif, dan R\&D. Bandung: Alfabeta.

Nistanto, K. Reska. 2016. Ini Negara dengan Jumlah Pengguna WhatsApp Terbanyak di Dunia. Tekno Kompas. http://tekno.kompas.com/read/2016/11/17/06150017/ini.negara.dengan.jumlah.pengg una.whatsapp.terbanyak.di.dunia

Singgih, Suparwoto. 2018. Pengembangan Media Belajar Mandiri Berbasis Aplikasi Whatsapp Untuk meningkatkan Motivasi dan Hasil Belajar Fisika Kelas XI SMA N 1 Purwokerto. Universitas Negeri Yogyakarta.

Aji, H. S. 2018. Pengembangan Aplikasi Layanan Pesan Instan Whatsapp Sebagai Sumber Belajar Mandiri Untuk Meningkatkan Motivasi Dan Hasil Belajar Fisika Materi Pokok Efek Rumah Kaca Peserta Didik Kelas XI SMAN 1 Purwokerto, Skripsi. Program Studi Pendidikan Fisika, Fakultas Matematika dan Ilmu Pengetahuan Alam, Universitas Negeri Yogyakarta.

Falahudin, I. 2014. Pemanfaatan Media dalam Pembelajaran. Jurnal Lingkar Widyaiswara, 1(4), 104. Retrieved from www.juliwi.com

Pranajaya, \& Wicaksono, H. (2017). Pemanfaatan Aplikasi Whatsapp (WA) di Kalangan Pelajar (Studi Kasus di Mts Al Muddatsiriyah dan Mts Jakarta Pusat). In Prosiding SNaPP2017 Sosial, Ekonomi, dan Humaniora (pp. 98-109). unisba.ac.id.

Al Qalam: Jurnal Ilmiah Keagamaan dan Kemasyarakatan

Vol. 15, No. 1, Januari-Juni 2021 